\title{
Analysis of Space Manipulation in an Informal Urban Settlement: The Case of Ng'ombe in Lusaka, Zambia
}

\author{
Jonathan Simbeya Mwamba ${ }^{1}$ \\ ${ }^{1}$ College of Architecture and Urban Planning, Tongji University, Shanghai, China \\ Correspondence: Jonathan Simbeya Mwamba, College of Architecture and Urban Planning, Tongji University, Siping \\ Road, Shanghai, China.
}

Received: August 14, 2020

doi:10.11114/ijsss.v8i6.4971
Accepted: September 30, $2020 \quad$ Available online: October 9, 2020

URL: https://doi.org/10.11114/ijsss.v8i6.4971

\begin{abstract}
Urban informality remains a consistent challenge and matter of debate by planners and policymakers in the urbanising cities of sub-Saharan Africa. A common manifestation of urban informality in African cities is the sprawling informal settlements that constitute the only available housing option for the majority of the urban poor. The analysis of informal urban settlement's environmental composition, physical modelling and socio-economic and policy analysis have been areas of recent study. However there is limited literature on how the urban poor communities in Zambia manipulate their social, spatial and economic environments to meet their needs. This article seeks to broaden the knowledge base on the way informal urban settlement communities manipulate their urban space. The built environment provides the setting for human interaction and the explanatory theory of Environment-Behaviour Relations provides a suitable analytical framework for the identification of useful parameters for developing future settlement interventions. The study employs a case study method of research to analyse the informal urban settlement settings. Ng'ombe, a peri-urban informal settlement in Lusaka, Zambia is the case study location for this research. Analysis of social, spatial and economic environment at neighbourhood level provides vital information about the informal urban settlement conditions. The study in particular addresses the question of how the social-spatial circumstances of the informal urban population in the developing world influence and defines their built environment. The study shows that systems of settings and system of activities in Ng'ombe offer a suitable analytical framework for studying the settlement characteristics that can guide in formulating strategies for settlement regularisation. Residents devise means of adapting and manipulating their informal urban space to suit their immediate needs and they also devise livelihood coping strategies in the midst of their informal settings. The paper likewise contributes to the growing body of knowledge in urban informality.
\end{abstract}

Keywords: informal urban settlements, urban informality, vulnerability, Komboni, systems of settings, systems of activities

\section{Introduction}

The combined effects of low incomes, limited affordable housing stock and exorbitant urban land prices limit access to legal and affordable housing for the majority of the urban poor. The quest to devise housing solutions for the urban poor beyond the realm of formality has led to the development of slums and informal settlements. Informal settlements are an established phenomenon and constitute a major part of the residential geographies of cities of the developing world. UN-Habitat (2008) estimates the slum population to be well over 800 million in the global south. Current estimates forecast $50 \%$ of the total urban population will be living in such settlements in the coming decade. However there is limited strategic focus on how to integrate these settlements into the city (United Nations, 2012). Interventions to the urban slum challenge over the last 6 decades have ranged from demolition to upgrading and redevelopment. These First world interventions meant for implementation in the Global South show no regard for the needs of residents of informal settlements. According to Duque (2002) and Rapoport (1990) current development interventions pay little regard to the needs and livelihoods of informal settlers and offer limited recourse to the challenges faced by the urban poor. Solutions to the informal settlement challenge require understanding the local systems that influence their existence, vulnerability and resilience. A thorough understanding of space production and manipulation is therefore essential in formulating development interventions best suited to the informal urban settlement setting

This paper uses at Ng'ombe informal urban settlement of Lusaka, Zambia as a case study to understand how residents of 
this settlement manipulate their built environment to suit their housing needs and livelihoods. The study objective was to understand how the systems of settings and embedded system of activities at settlement and neighbourhood level influence the built environment of Lusaka's informal urban settlements or komboni as they are locally known. The uniqueness of $\mathrm{Ng}$ 'ombe informal settlement including its housing needs, prevailing state regulations and current level of development intervention provide an ideal setting for analysing local housing dynamics from which lessons can be learnt to guide future social and spatial development interventions in similar informal urban settlements. It is important to understand resident's appreciation of their built environment, how they define the space settings in the settlement based on the activities they conduct in these settings. This includes the processes of production and use of space and the existing forms and types of space resulting from man environment interactions in the komboni.

\section{Literature Review}

\section{Urban Informality and Informal Settlements}

Sindzingre (2006),notes that informality can be observed based on the type of activities and the settings in which they occur. In her article on urban informality, Roy (2005) acknowledges that informal housing and land markets are an important domain for all in cities in the global south. Portes, Castells, and Benton (1989) postulate that informality is a result of the proliferating capitalism globally and ineffective government regulation enforcement. Whose remediation requires structural economic changes and improved regulation enforcement. Roy (2009) defines informality as a form of state deregulation, where the ownership, use and purpose of land cannot can't be mapped and fixed according to the law or any prescribed regulations (Roy, 2009).

De Soto (2000) observes that urban informality is the urban poor's coping mechanism for their condition of deprivation. De Soto (1989) first argued that state over-regulation encourages informality as the urban poor devise means of bypassing the unattainable standards expected in the formal economy. The urban informal sector offered economic flexibility to the urban poor. Such sentiments informed the World Bank's advocacy for deregulation and provisions of forms of tenure security as essential preconditions for slum improvement in the Global South. Others scholars take a more critical view of the state's arbitral use of its regulatory powers in placing the label of informality on various sectors while overlooking the fact that the state derives economic benefits from the same informal sectors (Roy 2005, 2009; Miraftab 2005). This highlights the important role of state and economic factors in determining informality. Informality also manifests outside of state regulation in different forms and to varying degrees of illegality. Besides focusing on the character of informal activities, it is necessary to also understand the limits of state regulation which define the extent of informality (Harris-white, 2010; Sindzingre, 2006).

Mukhija and Loukaitou-Sideris (2015) observe that urban informality is intrinsically linked to social and economic limitations. Urban informality studies have shown the potential of informal settlements to be an affordable housing option for the urban poor (Turner, 1972; De Soto, 1989). There however is a deficit of the requisite knowledge and resources for understanding urban informality which has led to poor management of the slum challenge (Elsheshtawy 2011; Dovey and King, 2011). Improving the lives of informal settlement residents remains one of the cardinal global development challenges of the 21st century (Fox, 2014). For the past 6 decades, informal settlements have been growing continuously in tandem with urbanization of the developing world (UN-Habitat, 2012). Informal settlements are characterized by a complex combination of substandard dwelling structures, overcrowding and lack of access to adequate water and sanitation facilities. The UN-habitat, (2003) acknowledges the levels of deprivation in such settlements. Reducing urban inequalities experienced in informal settlements requires effective urban planning. It is therefore imperative to understand the local dynamics at play in informal urban settlements.

\section{Informal Settlement Regularisation}

Berenstein-Jacques, (2001) observes that the inherent diversity in informal settlements confirms the presence of form and design language, which necessitates a further study of their built form. Lefebvre (1991) noted that every society produces its own space according to its norms. This necessitates the development of mechanisms for understanding the fabric and form of space (Cardosi \& Lizarralde, 2014). This is to understand how the society constructs space and how residents use it. When the poor and marginalised experience deprivation, they produce a counter-space to challenge authority or to compensate for the deprivation. The adequate provision of development interventions in informal communities requires a total comprehension of how the poor experience their built environment (Lefebvre 1991). State approaches to urban informality have transitioned from confrontational policies that sought to eradicate informal settlements to recent approaches of participatory upgrading (Richmond, Myers \& Namuli, 2018). Mukhija (2002) observes that recent studies on slum upgrading underestimate the potential impact of slum's physical conditions on successful housing improvement. Most studies make assumptions on the informal settlement's physical characteristics and neglect to appreciate how a thorough analysis of its physical attributes influences the development of strategies for settlement upgrading. Turner (1972) first suggested analysing existing informal housing standards when developing 
design parameters for slum housing programs. While Rybczynski and Bhatt (1984) showed how mapping the cultural use of public space in Indian slums unplanned settlements can help improve informal housing performance.

Some scholars have advocated on the benefits of informal settlement regularisation which include better housing, greater economic security and improved tax revenue for the state. A counter argument postulates that regularisation poses a threat to existing social networks in a community; it disturbs access to social capital and does not fully resolve the inherent structural deficiencies found in state regulated systems (Roy, 2005; Myers, 2016; Lince, 2011). Contemporary urban planning interventions should incorporate a bottom-up appreciation of informal settlement dynamics. An understanding of system of settings at different levels of the settlement should form the basis of the design solutions for the slum challenge. Analysis of the systems of settings and systems of activities in the komboni allows for an effective critique of its built environment and allows for the development of settlement specific development interventions (Cardosi \& Lizarralde, 2014)

\section{Environment-Behaviour Relations and the Built Environment}

According to Low (1996) built space is defined by the symbolism and function attached to it. Since the informal settlement space is likewise a built space, it should therefore be evaluated within its circumstances. Rapoport (2001) developed the explanatory theory of Environment-Behaviour Relations (EBR) to better understand the use and production of social space. The theory attempts to explain and empirically test the patterns and linkages between man and the environment. Rapoport (1980) observes that the main function of design is to improve the environment. Improving environmental quality is a goal of informal settlement upgrading. Several factors guide this function and are studied from a social, cultural, economic and political perspective. These factors guide man's desire to create a better environment. The field of Environment-Behaviour Relations (EBR) involves the structured evaluation of the interaction between man and his built environment. The built environment is the product of human interaction (Diang'a, 2011). Rapoport (2001) defines the built environment as a manifestation of local culture or a system of settings organized over space, time, meaning \& communication wherein systems of activities occur. Moffatt \& Kohler (2008) defines it as a composition of facilities constructed to meet human requirements. These facilities and their relative location create systems which define the composition of built elements, the land where they sit and the people they influence. It is vital to understand the systems and how they define space. The approach of dismantling environmental components offers an appropriate conceptual framework for evaluating the informal settlement space and addressing the issues of the impact of improvements on environmental quality including the aspects of compatibility, affordability, tenure systems and lifestyles. Thus a suitable study approach to the informal urban settlement would require an evaluation of forms of shelters, organization of space, system of settings, cultural landscape and other fixed, semi-fixed and non-fixed features, including all the actors within the study context.

\section{Vulnerability Context}

Vulnerability refers to an individual, household or community's risk of exposure to a hazard or their predisposition to harm when exposed to external stresses and from their inability to adapt (Moser, 1998; McCarthy et al., 2001; Adger, 2006; Birkmann, 2006). Vulnerability relates to the present prospect an individual has of being affected by future external risks, based on current events in his present environment. Vulnerability is evident where people are disadvantaged or marginalised when exposed to external risk, shock or stress as is often the case in informal settlement settings which are more susceptible to hazards (Thabane, 2015; Birkmann, 2006; McCordic, 2016). Far from being passive actors, humans possess the dynamic ability to prepare for, cope, mitigate, resist and recover against the effects of hazards (Stonich, 2000). The urban poor's lives are similarly directly influenced by their livelihoods, assets and adaptation strategies. This broadly translates into factors that influence their vulnerability and processes that guide it (Rakodi \& Lloyd-Jones 2002). The types of vulnerabilities that threaten urban livelihoods include; sudden shocks such as forced evictions and relocation; long-term trends related to rapid population growth, poverty, state policies and governance matters; seasonal weather cycles and financial upheavals. Mitigating the vulnerabilities influences housing and occupant conditions. The exposure of members of any given society to vulnerability varies with age, gender, physical, social, political, economic, locational and psychological attributes (McCordic, 2016). Cardosi \& Lizarralde (2014) assert the need for an analysis of urban informality which decodes the coping mechanisms of the urban poor. A review of the progression of vulnerability of communities helps develop an understanding of the pressures it exerts and aids in developing means of mitigating its effects along the casual chain. There is need to reduce vulnerability in order to reduce the cumulative effects of local pressures in the community.

The study thus first situates the komboni within the specific context, considering the existing environmental settings affecting housing for the urban poor. The article then considers man-environment interactions and finally assesses the livelihoods and vulnerabilities of informal urban settlement residents. The aim is to understand the wider spectrum of systems of settings in the informal urban settlement which can guide in formulating sustainable development strategies. 


\section{Methodology}

This study adopts the explanatory theory of environment-behaviour relations to study the informal settlement built environment. The Explanatory theory of Environment-Behaviour Relations (EBR) decodes the patterns, links and forms of interaction between environment and behaviour, including their mechanisms. Empirical data was collected from households in Ng'ombe informal settlement of Lusaka. A case study research was considered as an appropriate empirical inquiry for investigating a contemporary phenomenon within its existing context (Creswell \& Clark 2017:4; Yin, 2003, p. 13). Bell (1993:8) observes that an explanatory case study seeks to unveil the cause-effect of the studied phenomena. Ng'ombe informal urban settlement was selected based on its data richness, relative location, informal urban space dynamics and relevancy to the objective of this study (Neuman, 2011). The article draws upon fieldwork conducted in Lusaka, Zambia between June 2013, February 2014 and a revisit in March to June 2018 by the author.

Deliberate sampling was adopted in order to have purposeful selection of study samples ensuring only pertinent information was collected for the study (Kothari 2004:178). 5 clusters of almost 50 households each were selected in $\mathrm{Ng}$ 'ombe, as a sample of the whole settlement population. The population sample comprised of $5 \%$ of the settlement households. The study clusters were selected based on the physical characteristics of the buildings, network of roads and footpaths, open spaces, commercial and recreation activities and existing public facilities. The total population of 244 households interviewed during the household survey offered a manageable sample to carry out a qualitative study within a defined neighbourhood space, observing the ordering of space and related activities.

Primary data was collected from respondents using a combination of data collection tools. Structured questionnaires, key informant interviews and primary and secondary written sources were used to develop a deeper understanding of the study subject (Yin 2003). Semi-structured questionnaires were administered to the sample households. Direct observation and photographic documentation complimented the key research methods and provided more explanatory power to understanding life in Ng'ombe (Peimani \& Kamalipour, 2016). 24 key community informant interviews were conducted to establish the extent to which research findings could be generalized beyond the realm of the case study under examination. The informants included selected residents of $\mathrm{Ng}$ 'ombe, members of community-based organizations (CBOs), local politicians, and NGOs working in the community. Structured in-depth interviews with 8 key civic officials were conducted to enquire about the level of state involvement in informal urban settlement development. The heads of institutions responsible for urban development planning and service provision in informal settlements from the Ministry of Local Government and Housing, Lusaka District Planning Office and department heads for Housing and Social Services, Engineering Services, City Planning and Peri-Urban Management at Lusaka City Council, were interviewed.

Table 1. Study Units of Inquiry

\begin{tabular}{l|l|l|l|l}
\hline Ref. & Respondent/Participant & Population & Sample & Response \\
\hline 01 & Households & 6044 & 244 & $244(100 \%)$ \\
\hline 02 & Community Members & - & 24 & 24 \\
\hline 03 & $\begin{array}{l}\text { Local Government Ministry officers and Civic and Lusaka City } \\
\text { Council Officers } \\
\text { (City Planning, Housing and Public Health Departments ) and } \\
\text { Lusaka District Planning Officer }\end{array}$ & - & 8 & 8 \\
\hline
\end{tabular}

Source: Author

The methods used aimed at identifying aspects of spatial organization and utility within the komboni built environment at neighbourhood/community level; activity systems within this built environment and community engagement. This can only be achieved by firstly understanding and developing a perception of the informal settlement life. 


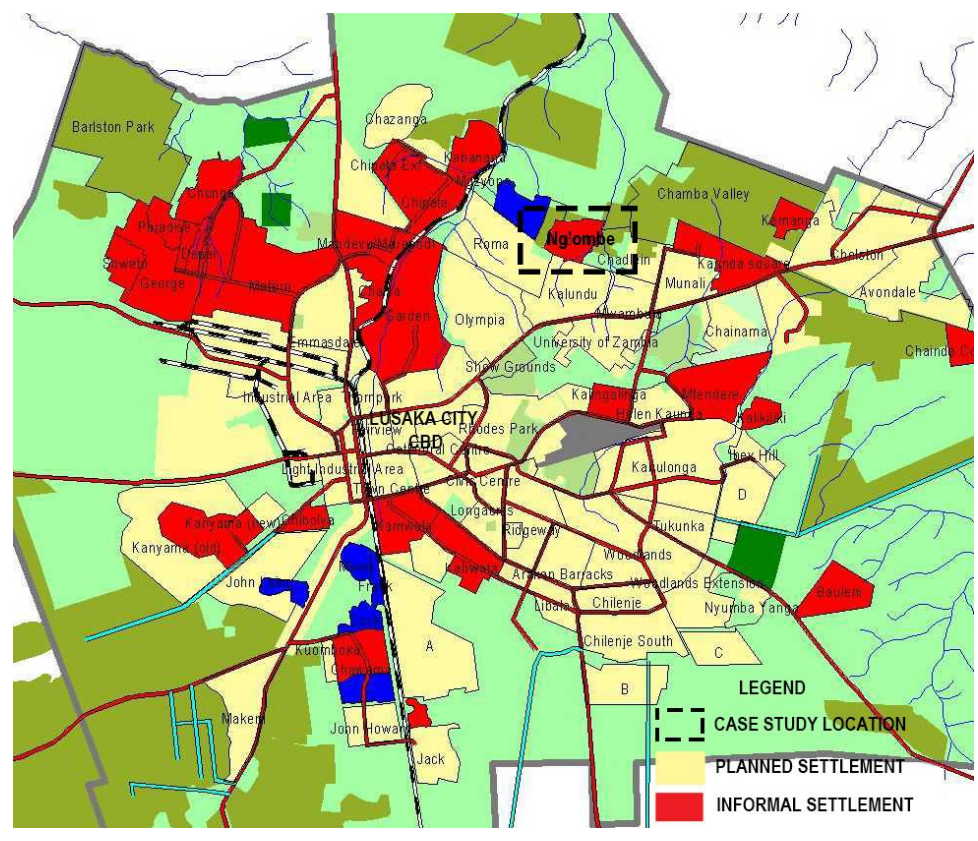

Figure 1. Location of Informal Settlements and Ng'ombe Settlement in Lusaka City

Source: LCC, 2012

\subsection{The Kombonis of Lusaka}

Ng'ombe settlement is located in the City of Lusaka in Zambia. Over 70 percent of Lusaka city's population live in its 37 informal urban settlements. These settlements are locally known as 'Komboni' which is an Africanised version of the word 'compound' in the local Nyanja dialect. These settlements are the remnants of colonial segregationist housing policies exacerbated by post independence rural-urban migration and rapid population growth (UN-habitat, 2007). Kombonis are areas occupied without right or legal title under government regulations. Lusaka's kombonis fall in two main categories: improvement areas (upgraded) and unrecognised settlements. The former are squatter settlements that have been accorded legal title for occupation and in some instances provided with basic service. The later are settlements that have not been granted legal title (Makasa, 2010). Lusaka's kombonis are found both in the inner city and on the city's periphery often starting on any land left undeveloped by the original owners or on parcels of land that were deemed uninhabitable or undesirable by the local authority.

Ng'ombe is a komboni or informal urban settlement with approximately 6044 households located on Lusaka City's northern urban periphery. The settlement of Old $\mathrm{Ng}$ 'ombe started in the 1930s as a small settlement for farm workers and later attracting migrants from parts of Lusaka and rural-urban migrants to the City attracted by the abundance of free land and cheap rentals. It was made up of poorly built houses made of mud walls and grass thatched roofs. The komboni received a site and service development programme in the late 1980s. The programme involved house re-blocking and resettling of displaced residents from the dense Old Ng'ombe compound to the overspill site later known as New Ng'ombe. The komboni was upgraded as an improvement Area, by the local authority and given legal status in 1999 under the Housing (Statutory and Improvement Areas) Act of 1974 (HSIAA). This granted a degree of tenure security for the home owners and protection from evictions and demolitions. This led many homeowners to make improvements and addition to their existing buildings with more permanent materials (LCC, 2006).Further settlement sprawl northwards was initially curtailed by the presence of a stream, which formed a natural boundary for new Ng'ombe. Despite this, a new settlement called Ng'ombe-Kasisi was created on illegally occupied land to the north of the stream. Although Ng'ombe komboni received legal status, the northern settlement of $\mathrm{Ng}$ 'ombe-Kasisi is still considered illegal under existing laws as it developed after the declaration and does not fall within the improvement area boundary. The Old Ng'ombe, New $\mathrm{Ng}$ 'ombe and $\mathrm{Ng}$ 'ombe-Kasisi are still collectively called Ng'ombe informal settlement and will be referred to collectively in this article.

\subsection{Why Ng'ombe Informal Settlement}

This study forms part of a broader study of 3 informal settlements in Lusaka. Ng'ombe represents one of the three settlement types used in the wider study that this researcher has been conducting. The study settlements represent an inner 
city settlement, an intermediate settlement and a Peri-urban or Peripheral settlement. Ng'ombe represents a peri-urban settlement used in the wider study. $\mathrm{Ng}$ 'ombe informal settlement was selected based on its (i) relative peri-urban location farthest from the Central Business district (CBD) on the periphery of the City of Lusaka, (ii) its unusually high population density, (iii) the unlimited and ever expanding settlement size, (iv) limited state-led development interventions, (v) the partially ordered building clustering of the settlement and (vi) existing tenant-building owner /landlord traits of the settlement.

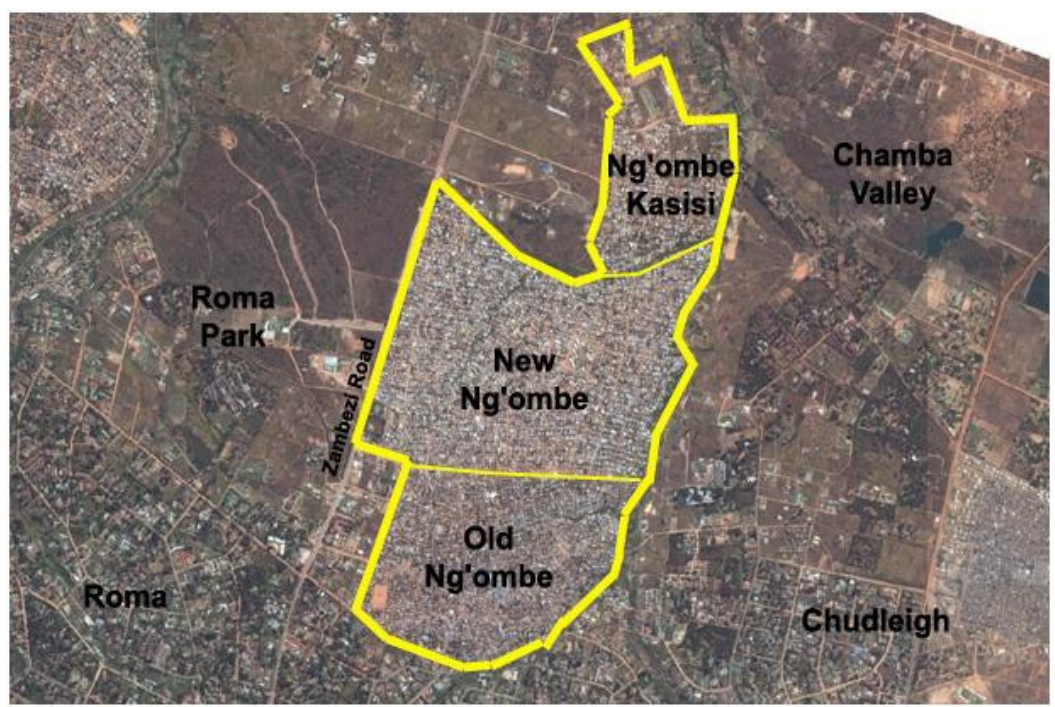

Figure 2. Ng'ombe Settlement and Surrounding Neighbourhoods

Source: Google Earth, 2014

\section{Systems of Settings Analysis Framework}

Albeverio et al. (2008) define a system as an assembly of interrelated components that function together through a driving process. The assembled components form blocks, compounds, neighbourhoods, and eventually settlements in the built environment. The framework of analysis for $\mathrm{Ng}$ 'ombe has been divided into three mains areas of focus namely; the population characteristics; system of settings and system of activities and; vulnerability of the settlers. These make up the three main themes of investigation conducted in the urban informal settlement of $\mathrm{Ng}$ 'ombe. The paper specifically considers behaviour in relation to system of settings and system of activities at neighbourhood level. The system of setting and system of activities in $\mathrm{Ng}$ 'ombe komboni is analysed on the basis of this conceptual framework in terms of the physical settings comprising of clustering of buildings in lots or blocks, zoning of space for facilities such as commercial, educational, social, recreational, religious and infrastructural facilities.

\subsection{Population Characteristics}

A study was conducted to understand the demographic composition of $\mathrm{Ng}$ 'ombe. This was done to establish a clearer picture of the main actors who have created and continue to define the physical characteristics that are observed in the community. Since EBR theory reflects the interaction of humans and the environment they occupy, it is only prudent that for any study of this nature a clear image of the Behaviour component of EBR is presented.

\subsection{Neighbourhood Systems of Settings and System of Activities}

Neighbourhoods are localities which are a product of the social interaction of dwellers living in close proximity. The study focussed on appreciating urban space creation, use and how daily activities define urban form at the neighbourhood level. The neighbourhood level was used as the level of investigation because of the multiplicity of ongoing activities in the komboni at this level. It is the main setting for public interaction in the komboni. Urban planning interventions are more effective at the settlement and neighbourhood level. The neighbourhood systems of settings and the setting of activities in $\mathrm{Ng}$ 'ombe where further studied and analysed along the physical, social and economic system of settings sub-themes (Dianga, 2011).

The physical setting reviews interactions taking place in the settlement's physical environment. Social setting in this context refers to the social and communal activities and facilities undertaken in the neighbourhood. The social settings considered included groups that address issues of education and health, evictions and tenancy, landlords and tenants, welfare and vulnerability, water and sanitation. Economic setting refers to the activities that the settlement dwellers 
undertake in order to generate income and earn a living. Thus observations document the various economic activities that take place in the settlement and the type of employment the respondents were engaged in.

\subsection{Vulnerability of Households}

This study limits itself to looking at drivers to vulnerabilities in the Ng'ombe komboni using a framework developed by Richmond, Malcomb \& Ringler (2015), which applies the BRIC methodology to highlight indicators that show household vulnerabilities in the informal urban settlement and identified 6 key vulnerability drivers in informal settlements (Richmond, Myers \& Namuli, 2018). Health, water and sanitation, food, livelihood, energy, and environment were identified as key drivers of vulnerability in the komboni. Other drivers of vulnerability in the settlement include threat of eviction, tenure insecurity, rapid population growth, poor access to social amenities, rent hikes, poor housing standards, fire risk, anti-social behaviour and hazards such as floods, changing weather conditions, erosion, environmental and noise pollution all of which constitute elements of vulnerability. Identifying the primary drivers of vulnerability helps pinpoint potential risks and develop mitigating measures.

Table 2. Case Study - General Analysis Framework.

\begin{tabular}{l|ll}
\hline Settings & & \multicolumn{1}{c}{ Factors Analysed in Ng'ombe Kombonis } \\
\hline Physical & $\bullet$ & Location and Coverage \\
& $\bullet$ & Clustering and densification \\
\hline Social & $\bullet$ Population and Housing \\
& $\bullet$ Administrative Organization \\
& $\bullet$ Community Infrastructure and Facilities \\
& $\bullet$ Onvironmental and Sanitation \\
\hline Economic & $\bullet$ Income Generating Activities (Livelihoods) \\
\hline Other Factors & $\bullet$ Vulnerability of households \\
& - History of the Settlement \\
\hline
\end{tabular}

Source: Author

\section{Findings}

The following section reviews demographic characteristics of the cluster populations used in the survey and proceeds to consider the systems of settings and the settings of activities in the study clusters. The settlement has undergone considerable densification and expansion over the years mostly in form of infill developments and illegal farmland encroachment which is still on-going to this day. It has also experienced limited development initiatives.

\subsection{Population Characteristics}

Characteristics of households considered here include household structures, level of education, skills, duration of stay in the settlement, and means of livelihoods. Male headed households comprising $80 \%$ of the household heads dominate the neighbourhood as shown in Table 3, while $20.1 \%$ of the study population were female headed households.

The prevalence of female headed households showed a large number of elderly women caring for grandchildren and extended families. This is attributed to the high mortality rates among men which leave widows to care for children and their children's children. The household structure study indicates that the extended family type dominates the households surveyed and constitutes 36.5 per cent of the households as indicated in Table 3.

Over two-thirds (72\%) of household head's spouses (Table 3) possess some form of formal education, indicative of a high literacy rate among the spouses. The existence of more primary level educated residents in Ng'ombe is another characteristic attributed to the lack of opportunities to further their education and indicates a high school drop-out rate.

Most household heads are involved in either formal or informal employment. The survey noted the common occupation among household heads was Domestic work (14.3\%) and security guarding (12.7\%) with bricklaying a close third (11.1\%) as indicated in Table 4. Most of the household heads are employed in the neighbouring low density townships and the city's CBD. No proof of formal or informal training was demanded during the survey and the accuracy of responses is dependent on the respondent's honest responses. The survey also noted that with the prevailing economic situation acquiring a trade did not necessarily influence an individual to move from $\mathrm{Ng}$ 'ombe to better residential settlements.

Table 3. Household Characteristics 


\begin{tabular}{|c|c|c|c|}
\hline Gender of Household Head & Frequency & Percent & Cumulative Percent \\
\hline Male & 195 & 79.9 & \\
\hline Female & 49 & 20.1 & \\
\hline Total & 244 & & 100.0 \\
\hline \multicolumn{4}{|l|}{ Household Relationship } \\
\hline Nuclear Family & 68 & 27.9 & 27.9 \\
\hline Extended Family & 89 & 36.5 & 64.3 \\
\hline Relatives & 51 & 20.9 & 85.2 \\
\hline Single Parent & 23 & 9.4 & 94.7 \\
\hline No Relation & 13 & 5.3 & 100.0 \\
\hline Total & 244 & 100 & \\
\hline \multicolumn{4}{|l|}{ Education Level } \\
\hline None & 67 & 27.5 & 27.5 \\
\hline Primary & 125 & 51.2 & 78.7 \\
\hline Secondary & 49 & 20.1 & 98.8 \\
\hline College & 3 & 1.2 & 100.0 \\
\hline Total & 244 & 100 & \\
\hline
\end{tabular}

Source: Author

Table 4. Occupation of Household Head

\begin{tabular}{|c|c|c|c|c|c|}
\hline \multicolumn{2}{|c|}{ Household head Occupation } & Frequency & Percent & Valid Percent & Cumulative Percent \\
\hline \multirow[t]{26}{*}{ Valid } & Unemployed & 12 & 4.9 & 4.9 & 4.9 \\
\hline & Unskilled labourer & 15 & 6.1 & 6.1 & 11.1 \\
\hline & Self Employed Carpenter & 8 & 3.3 & 3.3 & 14.3 \\
\hline & Self Employed Mechanic & 1 & 0.4 & 0.4 & 14.8 \\
\hline & Self Employed Welder & 2 & 0.8 & 0.8 & 15.6 \\
\hline & Self Employed Cycle Repairer & 1 & 0.4 & 0.4 & 16.0 \\
\hline & Self Employed Tailor & 1 & 0.4 & 0.4 & 16.4 \\
\hline & Vegetable Vendor & 11 & 4.5 & 4.5 & 20.9 \\
\hline & Food Vendor & 12 & 4.9 & 4.9 & 25.8 \\
\hline & Shop Keeper & 3 & 1.2 & 1.2 & 27.0 \\
\hline & Butcher & 1 & 0.4 & 0.4 & 27.5 \\
\hline & Barber & 3 & 1.2 & 1.2 & 28.7 \\
\hline & Cook & 6 & 2.5 & 2.5 & 31.1 \\
\hline & Preacher & 11 & 4.5 & 4.5 & 35.7 \\
\hline & Charcoal Seller & 6 & 2.5 & 2.5 & 38.1 \\
\hline & Herbalist & 1 & 0.4 & 0.4 & 38.5 \\
\hline & Bricklayer & 27 & 11.1 & 11.1 & 49.6 \\
\hline & Electrician & 14 & 5.7 & 5.7 & 55.3 \\
\hline & Driver & 12 & 4.9 & 4.9 & 60.2 \\
\hline & Painter & 5 & 2.0 & 2.0 & 62.3 \\
\hline & Security Guard & 31 & 12.7 & 12.7 & 75.0 \\
\hline & Clothes Vendor & 5 & 2.0 & 2.0 & 77.0 \\
\hline & Cobbler & 1 & 0.4 & 0.4 & 77.5 \\
\hline & Traditional Brewing & 8 & 3.3 & 3.3 & 80.7 \\
\hline & General Hawking & 12 & 4.9 & 4.9 & 85.7 \\
\hline & Domestic Worker & 35 & 14.3 & 14.3 & 100.0 \\
\hline Total & & 244 & 100 & 100 & \\
\hline
\end{tabular}

Source: Author

The duration of neighbourhood residency is an important factor in determining resident participation in community activities and neighbourhood development. The study shows over two-thirds of household heads $(68 \%)$ have lived in the community for over 16 years (See Table 5). The stable settlement population offers reasonable potential for participation in community development programmes. Since the opportunity for personal home ownership is high in Ng'ombe, people move into the settlement to build or buy property instead of renting in the inner city compounds and this creates a greater sense of belonging to the community as opposed to being a renting tenant.

Table 5. Duration of Stay in Settlement and Reason for Staying in Settlement

\begin{tabular}{ccccc}
\hline Duration of Stay in Settlement (Years) & Frequency & Percent & Valid & Cumulative \\
\hline
\end{tabular}




\begin{tabular}{|c|c|c|c|c|c|}
\hline & & & & Percent & Percent \\
\hline \multirow[t]{6}{*}{ Valid } & $1-5$ & 25 & 10.2 & 10.2 & 10.2 \\
\hline & $6-10$ & 23 & 9.4 & 9.4 & 19.7 \\
\hline & $11-15$ & 31 & 12.7 & 12.7 & 32.4 \\
\hline & $16-20$ & 66 & 27.0 & 27.0 & 59.4 \\
\hline & $21-25$ & 56 & 23.0 & 23.0 & 82.4 \\
\hline & Over 26 & 43 & 17.6 & 17.6 & 100.0 \\
\hline \multirow[t]{2}{*}{ Total } & & 244 & 100.0 & 100.0 & \\
\hline & Reason for Staying in Settlement & & & & \\
\hline \multirow[t]{4}{*}{ Valid } & Affordable Rent & 183 & 75.0 & & 75.0 \\
\hline & Affordable Rent/Proximity to place of work & 9 & 3.7 & & 78.7 \\
\hline & Affordable/Proximity to Self employment opportunity & 30 & 12.3 & & 91.0 \\
\hline & Affordability/Self employment & 22 & 9.0 & & 100.0 \\
\hline Total & & 244 & 100.0 & & \\
\hline
\end{tabular}

Source: Author

Most Ng'ombe household consider prevailing rental charges to be affordable (75\%) hence the reason they choose to live in Ng'ombe as indicated in Table 5. The rentals charges in Ng'ombe were found to be quite modest for the amount of space provided. Whereas US\$50 Dollars can get you a two-roomed multi-family flat in other slums the same amount of money will rent a two or three bedroom detached or semidetached house with separate kitchen room in Ng'ombe. The komboni's proximity to self employment opportunities (12.3\%) ranked second as a reason for staying in $\mathrm{Ng}$ 'ombe. Even though rentals are low in Ng'ombe the location of the settlement far away from the CBD makes it an undesirable location for low income people working in the CBD area.

\subsection{Neighbourhood Systems of Settings and Activities}

The systems of settings and the embedded systems of activities in $\mathrm{Ng}$ 'ombe include the physical settings, clustering of dwellings, networks of roads and footpaths, open spaces, commercial, social, religious and services elements.

\subsubsection{Physical Settings}

Ng'ombe is generally unplanned and comprised of mostly medium to high density, single storey tenements. It is surrounded by high-income low density housing settlements. It is lies within a radius of $10 \mathrm{~km}$ from the central business district of Lusaka with good a good connecting public transport network to other parts of the city. Ng'ombe is served by a trunk road (Zambezi road) running its western boundary and is accessible by road although $85 \%$ of internal roads are in a poor state. The komboni covers an area of 12,000 square meters $\left(12 \mathrm{~km}^{2}\right)$. The topography of the settlement is generally flat, sloping gently towards the two streams located on the northern and eastern edges of the settlement. The original Old $\mathrm{Ng}$ 'ombe settlement is made up of a mix of both mud brick and concrete block structures of mostly multi-family housing units. This part of the settlement has no organised system of dwelling layout and the access to areas of this part of the settlement is only by pedestrian footpaths.

New Ng'ombe exhibits a grid pattern formation with wide roads which allow for vehicular movement to all its parts. Unfortunately the conditions of the roads in the settlements are all of unmaintained gravel standard. The common housing types in this area include detached, semidetached and multi-family flat units. Ng'ombe-Kasisi is similarly characterised by a regular ordered dwelling layout defying its illegal unplanned origins. It has a low housing density and more accessible by vehicular traffic than Old Ng'ombe. The dwelling units in this part of the settlement are similar to those in New Ng'ombe. All parts of Ng'ombe komboni are provided with electricity and are supplied with treated water kiosks by the Ng'ombe Water Trust (WT). The settlement has no sewerage system leading to the majority of the population relying on pit latrines. The poor road network and nonexistent storm drainage system in the komboni exacerbate flooding and soil erosion in parts of the compound during the rainy season.

\section{i. Clustering of dwellings}

Old Ng'ombe is laid out in an irregular pattern with tightly grouped dwellings leaving little space for vehicular circulation and open spaces. New Ng'ombe and Ng'ombe-Kasisi exhibit a regular planned layout which is indicative of the development control measures employed in this part of the komboni by the planning agencies and neighbourhood development committees. The planning principle applied during the site-and-services upgrading of $\mathrm{Ng}$ 'ombe overspill neighbourhood saw the dominant economisation of services vis-à-vis the number of plots served with roads dominating the planning approach. Plots were set back-to-back with roads and storm water drainage in between. The spine roads have a width of 10 to 12 metres and traverse the neighbourhood. The feeder roads have 9 to 6 metre widths with the 6 meters wide roads being developed mostly as pedestrian walkways. During the survey it was noted that semidetached and 2 roomed multi-family housing blocks called 'Mudadada' were the prevalent housing type. The dwellings in the komboni are connected to one another by a network of narrow footpaths. The plot sizes allocated to residents in the area 
are generous, measuring between 12 metres wide by 20 metres long. The single storey dwellings are set back by 3 to 4 meters from the plot boundary and the access roads. This forms a transitional space between the dwelling and the more public access roads. The allocated plot sizes provide sufficient space for conducting household activities, urban agriculture and social interaction.

With the limited presence of local planning authority in Ng'ombe, new building construction has not respected these building setback lines. Some new structures have been built on plot boundaries and well beyond onto the access roads. The housing units however generally exhibit a well defined privacy gradient from public, semi public to semi private spaces. The popularity of building concrete block boundary walls for security by some household has also affected the amount of external usable space per dwelling. The generous spacing of dwellings in the newer parts of the settlement ensures a high level of privacy for the residents while the high density of dwellings in the older part of the Komboni effectively ensures a lower level of privacy but with better community cohesion.

\section{ii. $\quad$ Open Spaces between Buildings}

Open spaces within the clusters of building have transformed over the years in response to population and economic pressures. In the original grid-ironed Ng'ombe site and service planning layout, circulation and access had prominence over open spaces for other activities. The open spaces in between residences have been built over and the only remaining open spaces are incidental spaces where houses cannot be built.

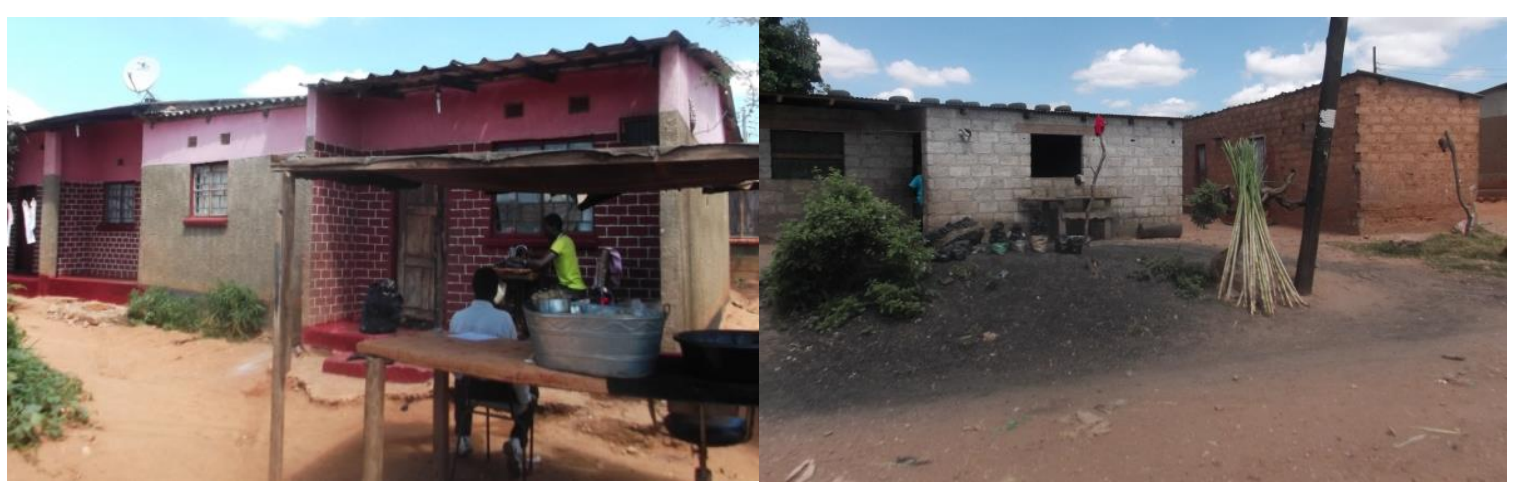

Figure 3. A tailoring business in New Ng'ombe with a food kiosk (Ntemba) in the foreground on a rental housing unit and; sugarcane and charcoal stand in front of 2 unfinished but occupied dwellings

Source: Author, 2018

Most residents have resorted to extending their dwellings or building multi-family housing blocks for rental purposes, further reducing the space between buildings. The available spaces between buildings act as a setting for informal trading, playgrounds, toilet facilities and gardens for subsistence farming. Presently designated open public spaces are a rare feature within the neighbourhood, except for 2 playgrounds near the government and private schools. The original area plan provided for open spaces in the neighbourhood which have since been built over by new settlers in the settlement. This is usually sanctioned by the ward development committee (WDC) or local ruling political party organs. The main commercial and recreational facilities are mainly located around the two main markets in the settlement. Similar to most settlements of Lusaka, makeshift kiosks locally called 'Ntemba' line most of the dwelling frontages from which a variety of everyday household items are sold (see figure 3). Currently the area's wide roads act as open spaces and the setting for social interaction and trading places. 


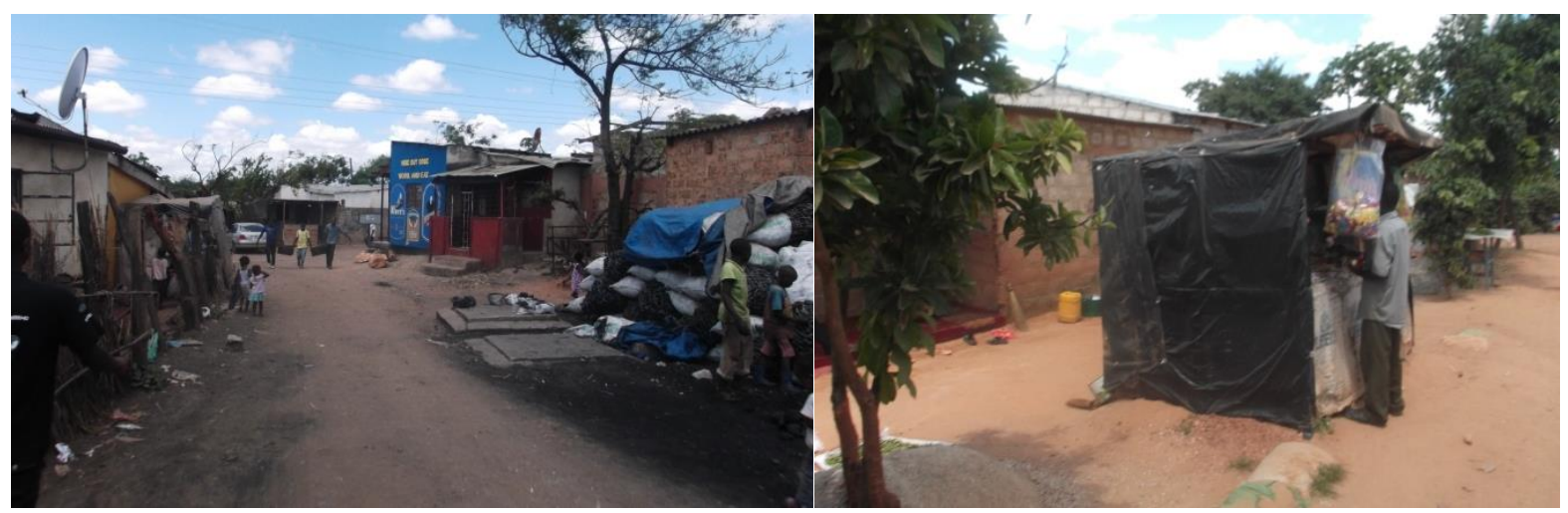

Figure 4. Typical Use of Space between Buildings in Ng'ombe komboni. Source: Author, 2018

The open spaces along the roads as mentioned earlier are commonly used as trading areas for various goods, neighbourhood meeting places and children's playing areas. These spaces have however assumed the informal role of dumping grounds for garbage. Even though there is a waste management system in place, it is common to see piles of garbage lining the neighbourhood streets.

\section{iii. Spatial needs}

The majority of Ng'ombe residents (88.9\%) claimed to be satisfied with their spatial environment. Respondents indicate that their dwellings had sufficient space for various activities such as crop cultivation, trading, food preparation, relaxing and hosting visitors. $11.1 \%$ expressed dissatisfaction with the spatial conditions. The majority of respondent who were not satisfied with the spatial conditions where localised to Old Ng'ombe which has inherent clustering challenges as it has experienced limited transformation since the settlement was established.

Table 6. Spatial Needs of Komboni Residents

\begin{tabular}{lcrrrrr}
\hline & Are Resident's Spatial Needs Met? & Frequency & Percent & $\begin{array}{r}\text { Valid } \\
\text { Percent }\end{array}$ & $\begin{array}{r}\text { Cumulative } \\
\text { Percent }\end{array}$ \\
\hline Valid & Yes & 217 & 88.9 & 88.9 & 88.9 \\
& No & 27 & 11.1 & 11.1 & 100.0 \\
Total & & 244 & 100.0 & 100.0 & \\
\hline & & & & & \\
\hline Valid & Is the Accommodation Satisfactory? & 226 & 92.6 & 92.6 & 7.4 \\
& Yes & 18 & 7.4 & 7.4 & 100.0 \\
Total & No & & 244 & 100.0 & 100.0 & \\
\hline
\end{tabular}

Source: Author.

Most of the detached housing in Ng'ombe Komboni is owner occupied while the semi-detached and multi-family units are mostly rental units. It was also noted that most landlords of the rental units were also accommodated within the rental premises. Most household heads (92.6\%) were satisfied with their accommodation (see table 6).

\section{iv. Public Infrastructure}

Public infrastructure in the compound is poor and generally lacking. The road network is generally poor, un-tarred and most roads are impassable during the rainy season. The system of roads around the settlement ensures that most of the settlement is accessible by vehicular traffic and for the inaccessible areas a system of footpaths ensure linkage to these areas. A bridge has been built to link New Ng'ombe to Ng'ombe-Kasisi. 


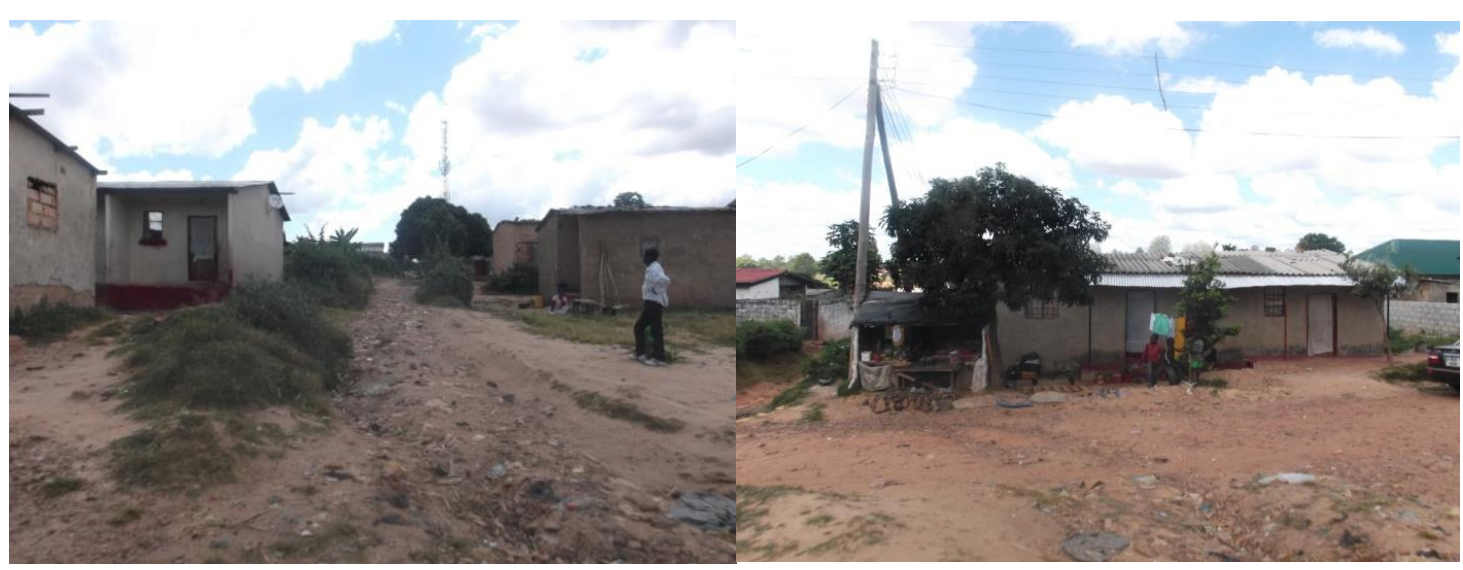

Figure 5. Dilapidated Road Network in Ng’ombe Kasisi komboni

Source: Author, 2018

During the study it was noted that $\mathrm{Ng}$ 'ombe has no water and sewerage systems. This has led to an overdependence on pit latrines $(85 \%)$ with only $15 \%$ residents having residential septic tank and soak-a-way sewerage systems. From the focus groups it was established that the Water Trust set up in the settlement provides communal water kiosks. Water wells were observed around the settlement despite community leaders discouraging their use due to risk of contamination and diseases. Water boreholes are also drilled on individual plots without planning control and safeguards to ensure it is treated for human consumption.

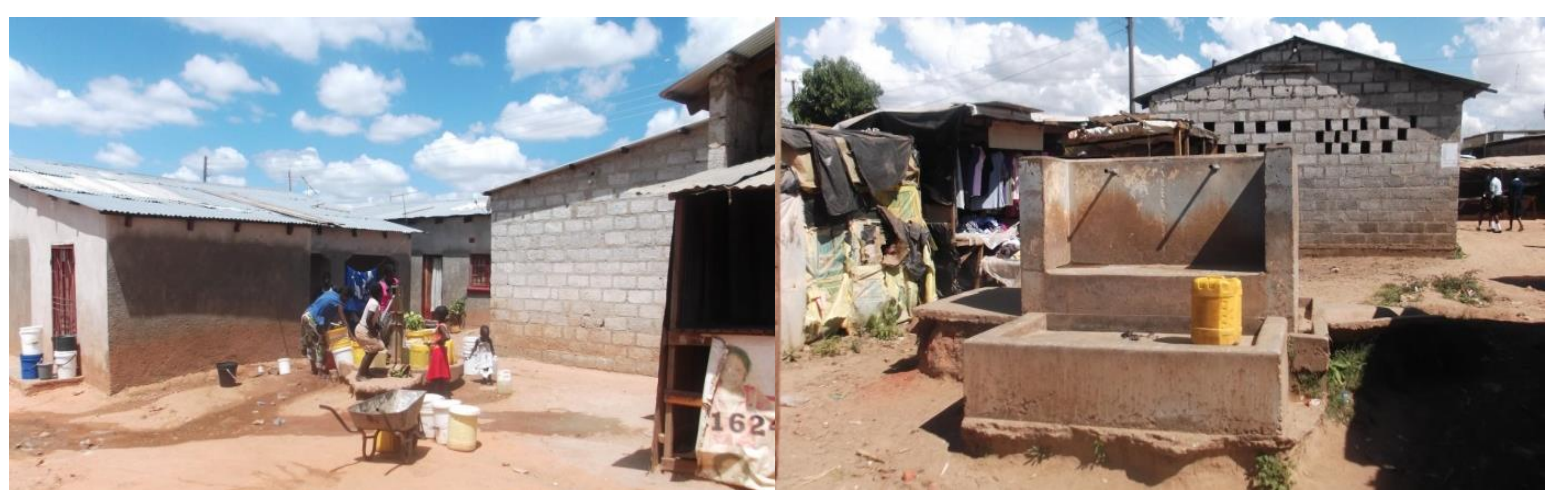

Figure 6. A borehole hand pump and disused water stand managed by the Water Trust in New Ng'ombe Source: Author.

A total of four (04) Community Based Enterprises (CBEs) involved in waste management were found managing garbage collection and disposal. 2 BCEs have since been inactive due to the lack of skip bins for waste collection. General apathy was observed towards paying for garbage collection, which has resulted in the illegal dumping of garbage on open spaces, abandoned buildings and into the stream that borders the settlement as indicated in figure 7 . The local authority similarly lacks the capacity to inefficiently collect garbage in the settlement. 


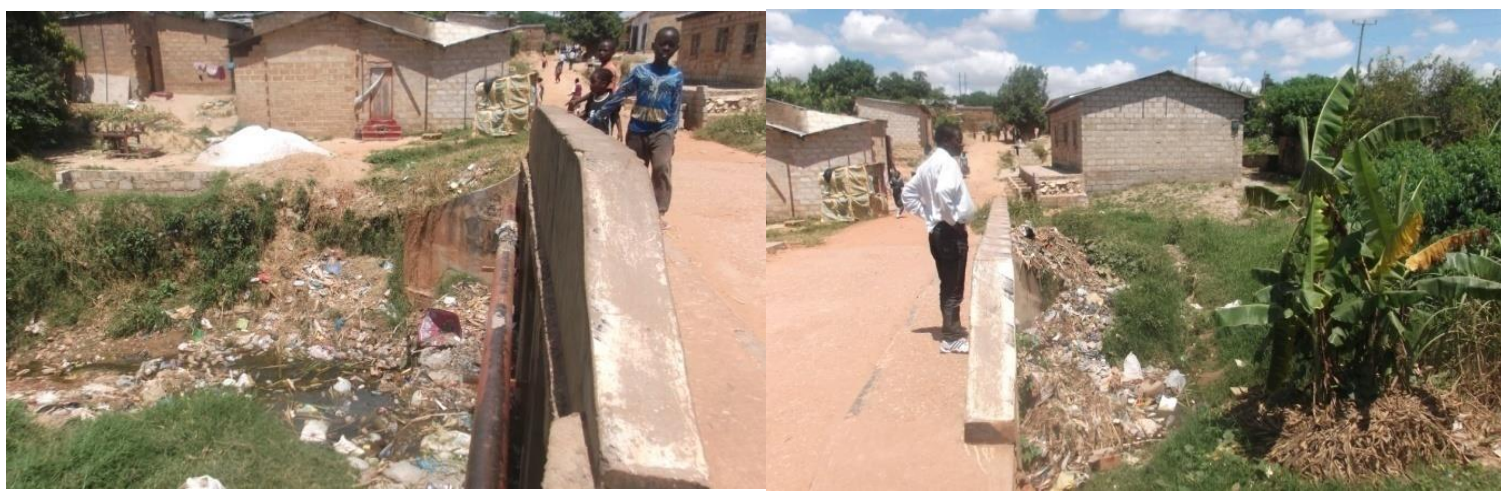

Figure 7. Garbage Dumping on Bridge Linking New Ng'ombe to Ng'ombe-Kasisi

Source: Author.

Despite this the focus group claimed that $\mathrm{Ng}$ 'ombe is regarded as one of the cleanest kombonis in Lusaka. Other public facilities found in the komboni include a clinic, two government primary schools and a police post which serves Ng'ombe and neighbouring informal settlements.

\section{v. Town Planning Considerations}

The local officials advised that the settings for infrastructure in New Ng'ombe were based on planning guidelines for low-cost housing as applied to developing countries. Local authority standards were applied in the demarcation of plots, construction of roads, storm water drainage and water supply. There was however, no planning control on the type of structures to be built in the settlement by the local authority. This has led to the abrogation of planning guidelines and increasing densities in the new areas of the settlement. Since old $\mathrm{Ng}$ 'ombe and $\mathrm{Ng}$ 'ombe-Kasisi began as slum settlements, they do not have any layout planning. According to the council authorities, they are not obliged to provide planning services because of the improvement area status of the whole komboni. They are only obliged to assist with planning control in cases of encroachment, building disputes and planning guidance when approached by government agencies and NGOs intending to provide development assistance to the settlement.

\subsubsection{Social Setting}

During the field visits it was observed that the system of social organisation in Ng'ombe is managed by the Ward Development Committee (WDC) headed by the area councillor. At neighbourhood level there are systems of social organisation presided over by an elder or older landlord who the other tenants consult over neighbourhood disputes. The political activism in the community showed that over 70 percent of the residents identified with the governing party. A number of Community Based Organisations (CBO) have established permanent operations in the community. 'Youths on a Mission' is one youth group running a skills training centre in the komboni. There are over seven women's groups in the settlement and two cultural groups. The churches organisations run a number of men's, women's and youth groups for their congregants. The Komboni has experienced a proliferation of religious Pentecostal organisations with their numbers being disproportionately higher than older more established Episcopal organisations. Similarly a number of Non-Governmental Organisations (NGOs) operate in the Komboni. These include;

- Care international, involved in water and sanitation provision;

- Zambia Open Community Schools (ZOCS) which provides education services to children in the settlement;

- Needs Care, which provides support to orphans and vulnerable children and adult education;

- Chikumbutso which is involved if education services;

- Ng'ombe community health watch group involved in health education, sensitisation and counselling;

- Keeper Zambia foundation involved in providing water and sanitation education and services and;

- Poor people's federation which provides eco-toilets to the community;

- Human Settlements of Zambia (HUZA) providing participatory upgrading and poverty reduction interventions.

Despite the observed high number residents $(80.4 \%)$ who have resided in the settlement for over 10 years (refer to table 5) there exists a high level of apathy towards neighbourhood affairs by komboni residents as highlighted by the key informant discussions. This is a matter which requires further investigation.

\subsubsection{Economic Settings}

Economic setting incorporates the approaches residents take to meet their economic needs and includes activities 
conducted within the dwelling, the neighbourhood or elsewhere in the city. Many residents earn their livelihoods through employment outside the neighbourhood. However, there are a number of informal economic activities that take place within the neighbourhood. Most residents are involved in the service and security industry as indicated in table 4 . The other main employment demographics are the people engaged in the construction sector who seek employment in the nearby localities and in Ng'ombe. Another thriving economic activity is the provision of rental housing in the settlement by landlords. The WDC officials during the interview put the figure of rental housing in the settlement at $75 \%$ of the total housing stock. Commercial activities are concentrated at the two main designated markets in the settlement and along the main thoroughfares. These include numerous small shops, food outlets and used clothes stands. Home-Based Enterprises (HBEs) are also an important means of livelihood for a large proportion of Ng'ombe households. Residents make use of their homes for a range of economic activities such as subletting of rooms in houses, informal trading on residential premises and village industries such as welding and carpentry. Commercial activities of a recreational nature including bars, taverns, makeshift video gaming, gambling slot machines and betting halls are also common and are located near the main trading areas.

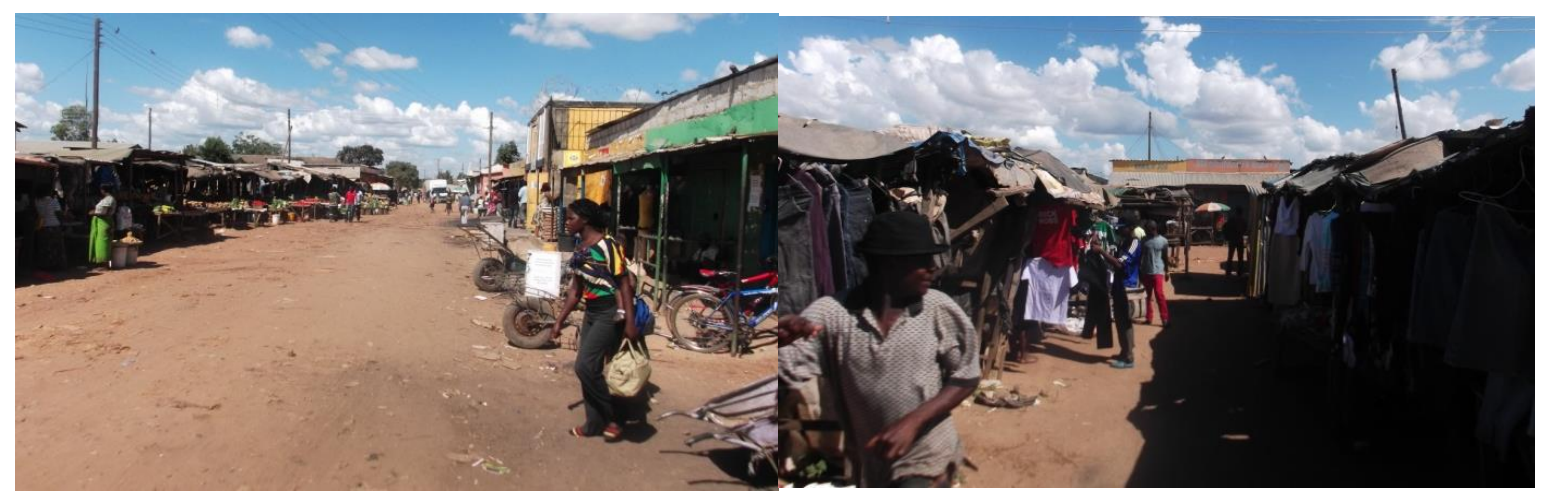

Figure 8. Main Commercial Activities Are Mainly Located Around the Market in New Ng'ombe

Source: Author.

\subsubsection{Maintenance of Upgraded Komboni Area}

The challenge that the local authority has faced in Ng'ombe is the maintenance of installed infrastructure. This is due to the lack of finances and capacity to conduct maintenance. Another main reason has been the lack of institutionalised maintenance planning which is endemic in all public offices. The city management have never seen maintenance of the facilities as a priority even when funds in successive budgets are allocated for such exercises. The residents also lack resources to undertake such maintenance repairs. This has led to deterioration of the facilities and services provided.

\subsection{Vulnerability of Households}

During the vulnerability assessment survey a number of key priority areas were established and ranked in order of importance, with Priority 1 being the most important to the settlement respondents and Priority 6 being the least important. The two main drivers of vulnerability in Ng'ombe were identified as health and access to water and sanitation. Other common concerns were electricity, security, garbage collection, education and roads. These everyday hazards constitute the main cause of disasters in the komboni (Bull-Kamanga et al., 2003). 


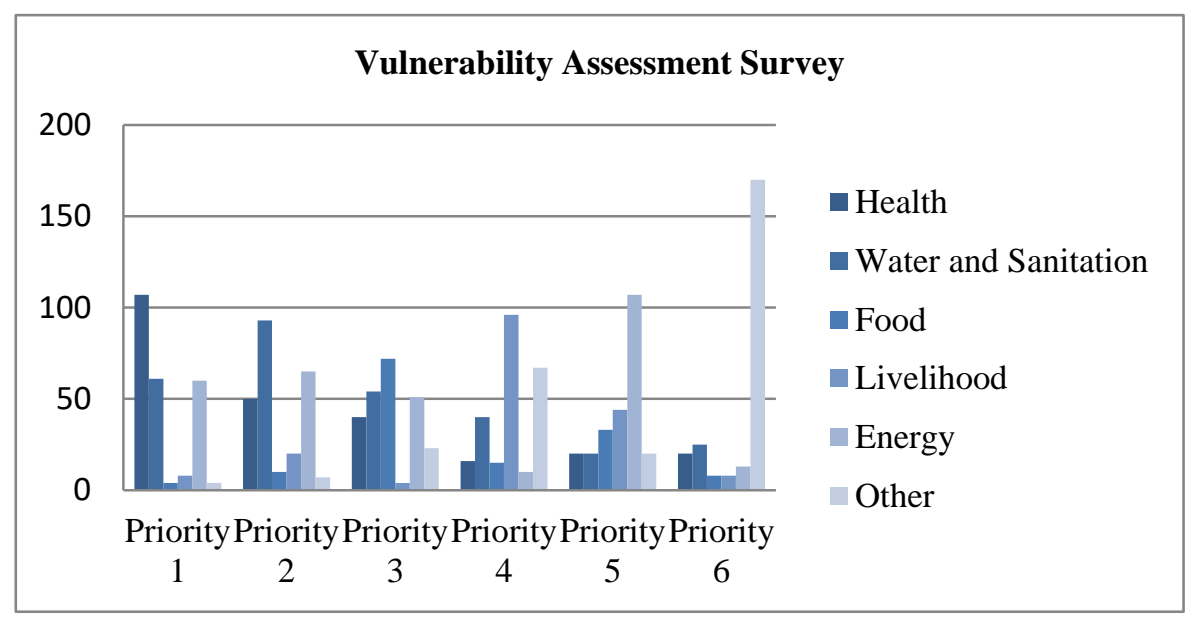

Figure 9. Vulnerability Assessment Survey of Ng'ombe Komboni

Source: Author.

The neighbourhood clusters surveyed identified critical settlement priorities as shown in figure 9 . The priority listed as other includes education opportunities, solid waste, social amenities, access to public services and access to electricity. The real vulnerabilities in the komboni relate to health, water and sanitation and food scarcity. Health tops the list of household vulnerabilities. The main health challenges relate to waterborne diseases brought on by water bodies (streams) and the drawing of household water from shallow wells. Common diseases in the community include malaria, cholera, bilharzia and diarrhoea. The rise of food prices during the wet and dry seasons of the year leads most households to ration meals. It is common for households to subsist on one meal a day. The lack of livelihood opportunities in the form of employment and trading opportunities are further impacted by the lack of electricity in the komboni. The area has been devastated by fires in the past due to prevalence of combustible materials used in the construction of dwellings. Flooding is a seasonal hazard and affects those living close to the stream. The rains also bring about incidences of collapsing houses due to the poor construction, contamination of water sources and impassable roads. During focus group discussions respondents pointed to the lack of youth employment opportunities and emergence of delinquent youth gangs has made neighbourhood security a common source of concern. This is despite the komboni having a new police post and a long established neighbourhood watch group. On the komboni boundary with high cost low density settlements, rental values have increased steeply spurred by prospective developments by private developers hoping to cash in on the areas proximity to formal settlements. This has priced out many of the original tenants who have had to seek cheaper accommodation further within the settlement thereby disrupting their livelihood settings.

\section{Discussions}

The population dynamics of Ng'ombe show a stable population that contributes to both the formal and informal economies of the city. Ng'ombe remains one of the critical human resource pool for various sectors in Lusaka. Ng'ombe komboni proves that tenure security encourages permanent improvement and investment in individual housing. The provision of limited tenure to komboni residents has encouraged residents to make permanent developments on their lots as the threat of future eviction is eliminated. The guarantee of tenure security appears to be a driver for improved housing conditions and should be considered as a primary requirement in future planning for other informal settlements. Despite the state of informality, Ng'ombe remains a major source for rental housing for new migrants to the city. The growth of low cost rental housing stock in the settlement should thus be encouraged. The thriving informal commercial scene shows the potential for residents to be fully self sustaining if more livelihood opportunities are present. The designation of the 2 commercial zones in the komboni has allowed for less congested roads. While allowing roads and footpaths to assume a semi-private character by encouraging commercial activities increases the residents' livelihood prospects and reduces economic vulnerabilities. The prevalence of informal commercial trading on public thoroughfares, road frontages and residential premises offers a thriving economic setting. Open spaces on individual plots are used for conducting household activities and food cultivation. Communal public spaces on the other hand are prone to neglect in instances where no function is ascribed to them. The indiscriminate dumping of waste in such spaces is a serious cause for environmental concern which has to be addressed in future development interventions. The observed grid layout of structures in the New Ng'ombe neighbourhood has contributed to the ease of service provision in this part of the komboni. The existing generous plot size, by informal settlement standards, in New Ng'ombe and Ng'ombe-Kasisi offer a setting 
for living, social interaction and commercial activities. The residents' satisfaction with their spatial condition indicates that the komboni environment offers adequate conditions for the urban poor households and the existing settings can be adopted and improved on for duplication in other kombonis.

The study also notes that lack of official planning control limits the provision of guidance in building development on individual plots. A degree of planning guidance is needed from either the local authority or local WDC to ensure minimum standards are observed. It was also noted that household participation in community initiatives aimed at settlement improvement has been low despite having a long established and beneficial NGO and CBO presence in the komboni involved in social development. There is need for concerted efforts to strengthen community organisation and advocacy to ensure increased community participation in future developments. Taking a page from the Water Trust's practices in the komboni, local authorities need to develop community based management systems for the administration of social and public infrastructure established in the komboni. The local WT management committees effectively manage and maintain the water infrastructure in their custody and this model should be adopted and scaled for public facilities in similar communities. Planning interventions which offer enabling livelihood opportunities are needed for overall sustainability.

\section{Conclusion}

It important to study how the urban poor manipulate and use space for their daily living if there is to be any attempt at improving the housing situation in informal urban settlements. When provided with enabling incentives such as security of tenure, the urban poor are able to make substantial positive improvements to their living environment and communities are able to organise themselves to better manage their social settings. Local management and support organs such as WDCs CBOs and NGOs provide a more effective means of community engagement with the urban poor than top-down state administration. Such structures can be effective agencies for delivering community development in informal urban settlements. Low rental accommodation in the komboni makes it a favoured option for the urban poor. The current manipulation of neighbourhood roads and plot frontages as trading spaces and resident's interaction space indicates the need to provide for similar infrastructure in future development intervention. The potential opportunity to engage in the informal economy and earn a living through the various economic activities taking place in these spaces is another reason why such organic coping strategies should be encouraged. Similarly generous building lines employed in New Ng'ombe, offer ideal settings for interaction at the dwelling and neighbourhood level and would be suitable for replication for future developments. Despite having challenges in health and education, the CBE model used to form the 4 waste management companies for garbage disposal and the WT for water and sanitation provision offer great promise and have the potential for scaling and replication to other informal settlements. Added efforts are needed in education, health, financial literacy and skills training facilities to help improve local livelihoods and reduce vulnerabilities in the komboni. The observed experiences and settings of activities from $\mathrm{Ng}$ 'ombe komboni can therefore be further used in devising development strategies that can replicate the positive organic transformations that the komboni has experienced. Vital information obtained in the analysis of the systems of the informal urban settlement built environment can be used to develop site specific intervention designs and strategies.

\section{References}

Adger, N. W. (2006). Vulnerability. Global Environmental Change, 16(13), 268-281. https://doi.org/10.1016/j.gloenvcha.2006.02.006

Albeverio, S., Andrey D., Giordano, P., \& Vancheri, A. (Eds.), (2008). The Dynamics of Complex Urban Systems: An Interdisciplinary Approach. Ascona. Switzerland: Monte Verità. https://doi.org/10.1007/978-3-7908-1937-3

Bell, J. (1993). Doing Your Research Project: A Guide for First Time Researchers in Education and Social Sciences. Milton Keynes, England: Open University Press.

Berenstein-Jacques, P. (2001). The Aesthetics of the Favela: The Case of an Extreme. In Fiori, J, Hinsley, H, Pascolo, E, Thornton, K. (Eds). Transforming Cities: Design in the Favelas of Rio de Janeiro. pp 28-30. London: Architectural Association.

Birkmann, J. (2006) Measuring Vulnerability to Promote Disaster-Resilient Societies: Conceptual Frameworks and Definitions. In Birkmann J. (ed). Measuring Vulnerability to Natural Hazards - Towards Disaster Resilient Societies. pp 9-54. New York: UNU-Press.

Blaikie, P., Cannon, T., Davis, I., \& Wisner, B. (2004). At Risk: Natural Hazards, People's Vulnerability and Disasters. (2nd ed.). New York, NY: Routledge. https://doi.org/10.4324/9780203974575

Bull-Kamanga, L., Diagne, K., Lavell A., Leon, E., Lerise, F., MacGregor, H., .. Reid, H. (2003). From Everyday Hazards To Disasters: The Accumulation of Risk in Urban Areas. Environment and Urbanization, 15, 193-204. https://doi.org/10.1177/095624780301500109

Cardosi, G., \& Lizarralde, G. (2014). Understanding Urban Form and Space Production in Informal Settlements: The Toi 
Market in Nairobi, Kenya. Proceedings of the 25th World Congress of Architecture: Architecture Otherwhere, pp. 1253-1270. South-Africa, Durban. UIA 2014, ISBN 978-0-86970-783-8.

Creswell, J. W., \& Clark, V. L. P. (2017). Designing and Conducting Mixed Methods Research. Thousand Oaks, CA: Sage Publications.

Diang'a, S. O. (2011). Regularizing Informal Settlements for Sustainable Housing Development for the Urban Poor: the case of Nairobi, Kenya. PhD thesis, University of Kwazulu-Natal.

Dovey, K., \& King, R. (2011). Forms of Informality: Morphology and Visibility of Informal Settlements. Built Environment, Volume 37, Number 1. Alexandrine Press. https://doi.org/10.2148/benv.37.1.11

Duque, E. (2002). 'House Form and Culture'Revisited: A Subaltern Critique of Rapoport's Reading. Third International Symposium of the Centre for Asian and Middle Eastern Studies. Adelaide: CAMEA.

Elsheshtawy, Y. (2011). The Informal Turn. Built Environment, 37(1). Alexandrine Press. https://doi.org/10.2148/benv.37.1.5

Fox, S. (2014). The Political Economy of Slums: Theory and Evidence from Sub-Saharan Africa. World Development, 54, 191-203. Elsevier Ltd. https://doi.org/10.1016/j.worlddev.2013.08.005

Harris-White, B. (2010). Work and Wellbeing in Informal Economies: The Regulative Roles of Institutions of Identity and the State. World Development, 38(2), 170-183. https://doi.org/10.1016/j.worlddev.2009.10.011

Kothari, C. R. (2004). Research Methodology: Methods and Techniques (2nd ed.). New Delhi: New Age International (Pty) Ltd.

Lefebvre, H. (1991). The Production of Space. (Translated by Nicholson-Smith D). Oxford: Blackwell.

Lince, S. (2011). The Informal Sector in Jinja, Uganda: Implications of Formalization and Regulation. African Studies Review, 54, 73-93. https://doi.org/10.1353/arw.2011.0029

Low, M. S. (1996). Spatializing Culture: The Social Production and Social Construction of Public Space in Costa Rica. American Ethnologist, 23(4), 861 - 879. https://doi.org/10.1525/ae.1996.23.4.02a00100

Lusaka City Council, (2006). A Report on the Status of Unplanned Settlements in Lusaka. LCC, Lusaka.

Lusaka City Council, (2012). Land Information Management for Chaisa: Chaisa Pilot Initiative. LCC, Lusaka

Makasa, P. (2010). The 1996 Zambia National Housing Policy. Ph.D. thesis. Delft Centre for Sustainable Urban Areas, Delft University of Technology, Delft.

McCarthy, J. J., Canziani, O. F., Leary, N. A., Dokken, D. J., \& White, K. S. (eds.). (2001). Climate Change 2001: Impacts, Adaptation and Vulnerability. Contribution of Working Group II to the Third Assessment Report of the Intergovernmental Panel on Climate Change. Cambridge: Cambridge University Press.

McCordic, C. (2016). Urban infrastructure and household vulnerability to food insecurity in Maputo, Mozambique. Ph.D. thesis. University of Waterloo, Ontario, Canada.

Miraftab, F. (2005). Informalizing the Means of Reproduction: The Case of Waste Collection Services in Cape Town, South Africa. In Beneria L. and Kudva N. (ed). Rethinking Informalization: Precarious Jobs, Poverty and Social Protection, 148-62. Ithaca, NY: Cornell University e-Publishing Program.

Moffatt, S., \& Kohler, N. (2008). Conceptualizing the Built Environment as a Social-Ecological System. Building Research \& Information, 36(3), 248-268. https://doi.org/10.1080/09613210801928131

Moser, C. (1998). The Asset Vulnerability Framework: Reassessing Urban Poverty Reduction Strategies. World Development, 26(1), 1-19. https://doi.org/10.1016/S0305-750X(97)10015-8

Mukhija, A., \& Loukaitou-Sideris, A. (2015). Reading the Informal City: Why and How to Deepen Planners' Understanding of Informality. Journal of Planning Education and Research 1-11, 35, 444-454. https://doi.org/10.1177/0739456X15591586

Mukhija, V. (2002). An Analytical Framework for Urban Upgrading: Property Rights, Property Values and Physical Attributes. Habitat International, 26, 553-570. https://doi.org/10.1016/S0197-3975(02)00019-X

Myers, G. A. (2016). Urban Environments in Africa: A Critical Analysis of Environmental Politics. Bristol, UK: Policy Press. https://doi.org/10.2307/j.ctt1t89fhr

Neuman, W. L. (2011). Social Research Methods: Qualitative and Quantitative Approaches (7th Ed.). Boston, Massachusetts.: Pearson.

Peimani, N., \& Kamalipour, H. (2016). Where Gender Comes to the Fore: Mapping Gender Mix in Urban Public Spaces. Spaces and Flows. An International Journal of Urban and ExtraUrban Studies, 8(1), 19-30. 
https://doi.org/10.18848/2154-8676/CGP/v08i01/19-30

Portes, A., Castells, M., \& Benton, L. (eds). (1989). The Informal Economy: Studies in Advanced and Less Developed Countries. Baltimore: Johns Hopkins University Press.

Pugh, C. (2000). Squatter Settlements. Their Sustainability, Architectural Contribution, and Socio-economic Roles. Cities 17(5), 325-337. https://doi.org/10.1016/S0264-2751(00)00029-9

Rakodi, C., \& Lloyd-Jones, T. Eds. (2002). Urban Livelihoods: A People-Centred Approach to Reducing Poverty. Earthscan. Sterling, VA. https://b-ok.cc/book/898728/2a185d

Rapoport, A. (1980). Towards a Cross-Culturally Valid Definition of Housing. In Stough R. R. and Wandersman A (eds). Optimizing Environments: Research, Practice and Theory, pp. 310-316. Washington D.C: EDRA.

Rapoport, A. (1990). The Meaning of the Built Environment: A Nonverbal Communication Approach. Arizona, USA: University of Arizona Press.

Rapoport, A. (2001). Theory, Culture and Housing. Housing, Theory and Society, 17, 145-165. https://doi.org/10.1080/140360900300108573

Richmond, A. K., Malcomb, D., \& Ringler, K. (2015). Household Vulnerability Mapping in Africa's Rift Valley. Applied Geography, 63, 380-395. https://doi.org/10.1016/j.apgeog.2015.07.013

Richmond, A., Myers, I., \& Namuli, H. (2018). Urban Informality and Vulnerability: A Case Study in Kampala, Uganda. Urban Science, 2, 22. https://doi.org/10.3390/urbansci2010022

Roy, A. (2005). Urban Informality: Toward an Epistemology of Planning. Journal of the American Planning Association, 71(2), 147-158, Chicago, IL. https://doi.org/10.1080/01944360508976689

Roy, A. (2009). Strangely Familiar: Planning and the Worlds of Insurgence and Informality. Planning Theory, 8(1), 7-11. https://doi.org/10.1177/1473095208099294

Rybczynski, W., \& Bhatt, V. (1984). How The Other Half Builds. Centre for Minimum Cost Housing, School of Architecture McGill University. Montreal.

Sindzingre, A. (2006). The Relevance of the Concepts of Formality and Informality: A Theoretical Appraisal. In Guha-Khasnobis B., Kanbur R. \& Ostrom E. (eds). Linking the Formal and Informal Economy: Concepts and Policies. Oxford: Oxford University Press. https://doi.org/10.1093/0199204764.003.0004

Soto, H de, (2000). The Mystery Of Capital: Why Capitalism Triumphs In The West And Fails Everywhere Else. London: Bantam Press.

Soto, H. de, (1989). The Other Path: The Economic Answer to Terrorism. New York: Basic books, 2002. 7-57

Stonich, S. (2000) The Human Dimensions of Climate Change: The Political Ecology of Vulnerability. Department of Anthropology and Environmental Studies, University of California.

Thabane, K. (2015). Determinants of Vulnerability to Livelihood Insecurity at Household Level: Evidence from Maphutseng, Lesotho. Journal of Agricultural Extension, 19(2). https://doi.org/10.4314/jae.v19i2.1

Turner, J. F. C., \& Fichter, R. (1972). Freedom to Build: Dweller Control of the Housing Process. New York: Collier Macmillan.

UN-Habitat. (2003). The Challenge of Slums - Global Report on Human Settlements 2003. London, UK: United Nations Human Settlements Programme.

UN-Habitat. (2007). Global Report on Human Settlements 2007: Enhancing Urban Safety and Security. London: Earthscan.

UN-Habitat. (2008). The State of African Cities: A Framework for Addressing Urban Challenges in Africa. Nairobi, Kenya: Un-Habitat \& UNEP.

United Nations. (2012). World Urbanization Prospects, the 2011 Revision. New York: United Nations Department of Economic and Social Affairs/Population Division.

Yin, R. (2003). Case Study Research: Design and Methods (3rd ed. Vol. 5) p. 13. Thousand Oaks, CA: Sage Publication.

\section{Copyrights}

Copyright for this article is retained by the author(s), with first publication rights granted to the journal.

This is an open-access article distributed under the terms and conditions of the Creative Commons Attribution license which permits unrestricted use, distribution, and reproduction in any medium, provided the original work is properly cited. 